\title{
Intake and Diet Selection by Protein Supplemented Grazing Steers
}

\author{
M.B. JUDKINS, L.J. KRYSL, J.D. WALLACE, M.L. GALYEAN, K.D. JONES, AND E.E. PARKER
}

\begin{abstract}
Nine esophageal-fistulated and 12 rumen-cannulated steers were randomly allotted to 3 equal supplement groups: cottonseed cake (CSC), ground, pelleted alfalfa hay (ALF), or no supplement (CON). Supplements were individually fed at isonitrogenous levels $\left(1.7 \mathrm{~kg} \cdot \mathrm{hd}^{-1}\right.$ CSC vs $3.5 \mathrm{~kg}^{\circ}$ hd $^{-1} \mathrm{ALF}$ ) every other day. Animals were maintained on treatment from January through April 1983 while grazing blue grama (Bouteloua gracilis) rangeland in southcentral New Mexico. Esophageal samples were collected at 2 times during this period: early February and late March; intake was estimated from total fecal collections in late February and early April. Esophageal samples were analyzed in the laboratory for nitrogen $(N)$ components, in vitro digestibility, fiber, and botanical composition. Animal selection for total grass content of the diet was not influenced $(P>.10)$ by supplementation but declined from February to March (31.8\% vs. $21.2 \%$, respectively). Blue grama and mat muhly (Muhlenbergia richardsonii) comprised over $66 \%$ of the grass component. Total forbs selected was not influenced by supplementation but increased $(P<.05)$ from February $(68.2 \%)$ to late March $(78.8 \%$ ), which may be the result of declining quantities of grass and emergence of forbs because of spring moisture. Dietary $\mathbf{N}$ components were not affected by supplementation. Soluble $N$, insoluble unavailable $N$, and crude protein were higher $(P<.05)$ in February than March as a result of increasing forb consumption and possible $\mathrm{N}$ leaching from grass. Fiber components, acid detergent fiber and acid detergent lignin, as well as organic matter digestibility of the diet, were not influenced by supplementation, and increased from February to March but only organic matter digestibility was higher $(P<.05)$ in late March than in early February. Forage organic matter intake was not influenced by supplementation $(P>.49)$, type of supplement consumed, or sampling period $(P>.90)$. Total organic matter intake however, differed $(P<.05)$ between treatment groups because of addition of supplements. Results of this study indicate protein supplementation of wintering steers does not ínfluence botanical or chemical composition of their diets or amount of forage consumed.
\end{abstract}

Improved weight gains and reproductive performance of protein supplemented cattle grazing dormant rangelands are well documented (Parker et al. 1974, Langlands and Bowles 1974, Falvey 1977, Adams and Kartchner 1983). Satisfying dietary requirements for nitrogen is a major mechanism involved in improved livestock performance; however, responses primarily limited to intake and digestibility have been noted (Campling 1970, Conrad 1966). Rit-

\footnotetext{
At the time of the study authors were graduate assistants, professor, associate professor, range technician and assistant professor, respectively; Department of Animal and Range Sciences, New Mexico State University, Las Cruces 88003 .

Review of the manuscript by Dr. J.L. Holechek was helpful and we appreciate his efforts.

Journal Article 1096, N.Mex. Agr. Exp. Sta., Las Cruces, N. Mex. 88003.

Manuscript accepted September 13, 1984.
}

tenhouse et al. (1970) reported forage intake increased upon addition of protein supplements to low-quality forage diets $(<6 \%$ crude protcin). However, results of other studies on the effect of supplements on forage intake have been varied (Weston and Hogan 1968, Rittenhouse et al. 1970). Effects of nitrogen supplementation on diet selectivity have not been investigated, although nutritional status has been proposed to influence preference (Heady 1964).

The objective of this study was to evaluate effects of 2 protein supplements, cottonseed cake and ground alfalfa pellets, on diet selectivity from the standpoint of botanical and chemical composition and forage intake.

\section{Study Area}

Field data for this study were collected at New Mexico State University's Fort Stanton Experimental Ranch in the foothillmountain region of southcentral New Mexico. Elevation of the arca is variable, but averages $1,950 \mathrm{~m}$ above sea level. Climate is mild, but cold weather can occur during the winter. January is the coldest month with a mean minimum of $-6.7^{\circ} \mathrm{C}$ and average date of last frost is 2 May. Winter precipitation (January to April) averages $55.9 \mathrm{~mm}$ with most occurring as snowfall (U.S. Department of Commerce 1973). Climate during the study period (January to May 1983) was characterized by an above-average precipitation of $84.1 \mathrm{~mm}$.

The study area was a 117-ha pasture fenced into 2 nearly topographically and vegetatively equal paddocks. Animals were allowed to graze the larger, 61-ha paddock 4 weeks before and during esophageal collections. The 56-ha paddock was used to maintain animals during nonsampling interval.

Both paddocks are similar in vegetative composition (Wallace et al. 1983). Major grasses are blue grama (Bouteloua gracilis), sideoats grama (B. curtipendula), sand dropseed (Sporobolus cryp. tandrus), mat muhly (Muhlenbergia richardsonii), ring muhly ( $M$. torreyi), wolftail (Lycurus phleoides), western wheatgrass (Agropyron smithii), and Halls panicum (Panicum hallii). Important forbs and shrubs are Carruth sagewort (Artemisia carruthi), tall globemallow (Sphaeralcea angustifolia), Dakota verbena (Verbena bipinnetifida), nuttall milkvetch (Astragulus nutallianus), buckwheat (Eriogonum spp.), fendler bladderpod (Lesquerella fendleri), broom snakeweed (Xanthocephalum sarothrae), and yucca (Yucca elata).

\section{Methods}

Nine esophageal-fistulated steers and 12 rumen-cannulated steers (average weight of $230 \mathrm{~kg}$ ) were randomly allotted to 1 of 3 treatments: control (no supplemental feed [CONI), mechanically extracted cottonseed cake (1.7 kg $\bullet \mathrm{hd}^{-1}$ [CSC]), and ground pelleted alfalfa hay $\left(3.5 \mathrm{~kg} \bullet \mathrm{hd}^{-1}\right.$ [ALF]). Supplements were individ- 
ually fed at the specified amounts (isonitrogenous) every other day from January to May. Individual feeding involved tethering animals to assigned feeding stations within a large pen. Chemical composition of supplements is shown in Table 1 . The supplementation level was chosen to represent winter supplementation levels recommended for ranchers in this region (Parker et al. 1974). Esophageal-fisulated and rumen-cannulated steers were driven into a central location on supplementation days at $0800 \mathrm{~h}$. Control steers were withheld from grazing while supplemented steers were fed. A salt-mineral mix (50\% dicalcium phosphate, $45 \%$ salt and $5 \%$ cottonseed meal) was provided free choice in the pasture.

Esophageal collections were obtained over 2 periods (midFebruary, and late March) from 3 steers per treatment group. Collections were made by penning all 9 steers before supplementation $(0700 \mathrm{~h})$. Animals were fed appropriate supplements and water was made available in the holding pen. Steers were fitted with collection bags and harnesses at $1600 \mathrm{~h}$ and released. Because the holding pen was centrally located, collection animals were allowed to walk to the remaining herd and graze for 15 to 30 minutes. No hazing or restriction was imposed on grazing behavior during collections.

Esophageal samples were composited across days so each steer had 1 sample per period representing a 3-day collection. Samples were frozen before laboratory analyses. In the laboratory, samples were dried at $50{ }^{\circ} \mathrm{C}$ for $48 \mathrm{~h}$ and ground to pass a $2-\mathrm{mm}$ screen. Dry matter and ash were determined by AOAC (1980) procedures. Neutral detergent fiber (NDF), acid detergent fiber (ADF) and acid detergent lignin (ADL) analyses were conducted according to procedures of Goering and Van Soest (1970).

Kjeldahl procedures were used for all nitrogen $(N)$ analyses (AOAC 1980). Nitrogen content of esophageal samples was fractionated into soluble (SN), insoluble (IN), insoluble available (IAN), and insoluble unavailable $\mathbf{N}$ (acid detergent insoluble, ADIN). Soluble and insoluble $\mathbf{N}$ fractions were determined by the
Table 1. Organic matter, crude protein and fiber components of protein supplements ${ }^{1}$ fed to steers graxing blue grama rangeland in southcentral New Mexico.

\begin{tabular}{lcc}
\hline & \multicolumn{2}{c}{ Supplement } \\
\cline { 2 - 3 } Component \% & $\mathrm{CSC}^{2}$ & ALF $^{2}$ \\
\hline Organic matter & 91.5 & 89.0 \\
Crude protein & 47.7 & 23.0 \\
Soluble nitrogen & 0.85 & 1.40 \\
Insoluble unavailable nitrogen & 0.31 & 0.15 \\
Neutral detergent fiber & 21.9 & 42.1 \\
Acid detergent fiber & 16.2 & 30.1 \\
Acid detergent lignin & 6.5 & 6.7
\end{tabular}

'All components expressed as a percentage of organic matter.

${ }^{2} \mathrm{CSC}=$ cottonseed cake; $\mathrm{ALF}=$ ground, pelleted alfalfa hay.

procedure of Waldo and Goering (1979). Insoluble available $\mathbf{N}$ is the portion remaining after $S N$ and $A D I N$ are subtracted from total $\mathbf{N}$.

The Tilley and Terry (1963) two-stage technique (48-hour rumen fluid, 48-hour pepsin digests) was used to determine extent of in vitro organic matter digestion (inoculum donor animals were fed alfalfa hay). Calcium (Ca) was determined by atomic absorption and phosphorus (P) by the molybdovanadate colorimetric procedure (AOAC 1980). All analyses except $\mathrm{Ca}$ and $\mathrm{P}$ were expressed on an organic matter basis.

Botanical composition of diets was determined using procedures outlined by Sparks and Malechek (1968). Five slides were made from each steer's sample and were examined until 50 fields of view were tallied with identifiable plant fragments. Dietary similarities between groups were calculated using Kulczynski's similarity index (Oosting 1956).

Table 2. Botanical composition (\%) of steer diets supplemented with ground, pelleted alfalfa (ALF) or cottonseed cake (CSC) on blue grama rangeland in south-central New Mexico.

\begin{tabular}{|c|c|c|c|c|c|c|c|}
\hline \multirow[b]{2}{*}{ Forage } & \multicolumn{3}{|c|}{ Sampling Date } & \multicolumn{4}{|c|}{ Treatment } \\
\hline & February & March & $\mathrm{SE}^{5}$ & Control & ALF & $\mathrm{CSC}$ & SE $^{S}$ \\
\hline \multicolumn{8}{|l|}{ Grasses: } \\
\hline Blue grama & $12.9^{\mathrm{a}}$ & $8.7^{b}$ & .19 & 11.4 & 10.2 & 10.7 & .15 \\
\hline Mat muhly & 8.4 & 6.2 & .18 & 7.3 & 6.9 & 7.2 & .19 \\
\hline Halls panicum & 2.5 & 1.7 & .12 & 3.0 & 2.0 & 0.8 & .11 \\
\hline Western wheatgrass & 1.7 & 2.1 & .08 & 3.2 & 1.8 & 1.8 & .06 \\
\hline Wolftail & $3.5^{\circ}$ & $1.3^{\mathrm{b}}$ & .09 & 2.4 & 1.5 & 3.8 & .08 \\
\hline Sand dropseed & $2.0^{n}$ & $0.0^{\mathrm{b}}$ & .08 & 1.1 & 1.2 & 0.8 & .08 \\
\hline Other grasses I & 0.8 & 1.2 & .08 & $\mathrm{~T}^{4}$ & 1.0 & 0.6 & .03 \\
\hline Total Grasses & $31.8^{\mathrm{A}}$ & $21.2^{\mathrm{b}}$ & .25 & 28.1 & 24.7 & 26.4 & .22 \\
\hline \multicolumn{8}{|l|}{ Forbs and Shrubs: } \\
\hline Carruth sagewort & 56.6 & 53.0 & .24 & 54.2 & 54.4 & 54.8 & .25 \\
\hline Scarlet globemallow & 3.9 & 2.5 & .13 & 3.2 & 3.7 & 2.6 & .14 \\
\hline Locoweed & 3.5 & 4.1 & .16 & 2.3 & 4.2 & 4.9 & .12 \\
\hline Dakota verbena & 1.7 & 3.2 & .11 & 2.6 & 1.8 & 2.7 & .11 \\
\hline Buckwheat & $0.0^{\mathrm{a}}$ & $5.5^{\mathrm{b}}$ & .13 & 3.3 & 2.1 & 2.9 & .13 \\
\hline Bladderpods & $0.0^{\mathrm{a}}$ & $2.1^{\mathrm{b}}$ & .10 & 0.9 & 2.2 & $T$ & .11 \\
\hline Snakeweed & 1.3 & 3.6 & .18 & 1.9 & 1.8 & 1.7 & .18 \\
\hline Yucca & $\mathrm{T}$ & 1.5 & .07 & 0.8 & 0.8 & 1.9 & .05 \\
\hline Other forbs ${ }^{2}$ & $T^{*}$ & $1.7^{\mathrm{b}}$ & .03 & $\mathrm{~T}$ & 1.4 & 1.2 & .06 \\
\hline Other shrubs ${ }^{3}$ & $\mathrm{~T}$ & $\mathbf{T}$ & .03 & $\mathrm{~T}$ & 0.7 & $T$ & .05 \\
\hline Total Forbs & $68.2^{*}$ & $78.8 \mathrm{~b}$ & .24 & 71.9 & 75.3 & 73.6 & .21 \\
\hline
\end{tabular}

'Includes: bottlebrush squirreltail (Sitanion hystrix), threeawns ( Aristida spp), and ring muhly.

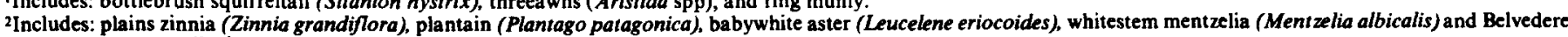
summer-cypress (Kochia scoparia).

IIncludes: fourwing saltbush (Atriplex canescens) and one-seeded juniper (Juniperus monosperma).

${ }^{4}$ Traces $(<.5 \%)$

'Standard error of the mean for sampling date or treatments.

, beriod means with different letters differ $(P<.05)$. 
Table 3. Chemical composition' of steer diets supplemented with ground pelleted alfalfa (ALF), cottonseed cake (CSC) or no supplement (CON) on blue grama rangeland in south-central New Mexico.

\begin{tabular}{|c|c|c|c|c|c|c|c|}
\hline \multirow[b]{2}{*}{ Component $\%$} & \multicolumn{2}{|c|}{ Sampling Date } & \multirow[b]{2}{*}{$\mathrm{SE}^{2}$} & \multicolumn{3}{|c|}{ Treatment } & \multirow[b]{2}{*}{$\mathrm{SE}^{2}$} \\
\hline & February & March & & CON & ALF & $\mathrm{CSC}$ & \\
\hline Organic matter & $82.6^{a}$ & $79.3^{b}$ & .55 & 81.2 & 81.2 & 80.5 & 1.0 \\
\hline Neutral detergent fiber & 80.7 & 78.0 & .68 & 80.3 & 79.7 & 78.1 & 2.3 \\
\hline Acid detergent fiber & 62.3 & 65.4 & .90 & 63.4 & 63.4 & 64.8 & 1.2 \\
\hline Acid detergent lignin & 9.3 & 10.7 & .40 & 9.6 & 9.3 & 11.1 & .60 \\
\hline Organic matter disappearance & $42^{\mathrm{a}}$ & $48^{\mathrm{b}}$ & .15 & 45 & 45 & 46 & .15 \\
\hline Calcium & .70 & .84 & .03 & .76 & .78 & .77 & .04 \\
\hline Phosphorus & .22 & .23 & .01 & .22 & .23 & .24 & .01 \\
\hline
\end{tabular}

'Diet composition as a percentage of organic matter except for calcium and phosphorus which are expressed as percentage of dry matter. 2SE = Standard error of the mean.

a, Sampling date means followed by different letters differ $(P<.05)$.

Total fecal collections were conducted in late February and early April (2 weeks following diet sampling) using the rumen-cannulated steers. It was assumed that changes in forage chemical and botanical composition would be minimal over the 2-week interval between esophageal and fecal collections. Collection bags were placed on the steers for 5 consecutive days and bags were changed every 12 hours. Fecal collections were emptied into plastic sacks and stored at $4^{\circ} \mathrm{C}$. When each 24-hour collection had been obtained, bags were combined to represent a 24-hour collection for each steer. Feces were weighed, mixed, and a subsample of $500 \mathrm{~g}$ was obtained. Each steer's daily subsample was frozen until dry matter and organic matter were determined. Organic matter intake was estimated using fecal organic matter output and diet in vitro organic matter indigestibility.

Data were analyzed as a split-plot design with supplement as the main plot and sampling period as subplot treatment. The least significant difference procedure was used in comparing means following preliminary $F$ tests by analysis of variance (Steele and Torrie 1980). No supplement by sampling period interactions were noted for any of the data analyzed.

\section{Results and Discussion}

Botanical composition of steer diets revealed no effect $(P>.10)$ of supplementation on animal dietary selectivity; however, collection period differences $(P<.05)$ were noted (Table 2$)$. Total grass content of diets declined $(P<.05)$ between February $(31.8 \%)$ and late March (21.2\%). This decline was typified by reduced selection $(P<.05)$ of blue grama, wolftail and sand dropseed. However, at both samplings, blue grama and mat muhly comprised over $66 \%$ of the grass component. Other investigators have reported grasses to be the most important component of cattle diets on Utah desert ranges (Cook et al. 1963) and California annual grasslands (Van Dyne and Heady 1965). However, Pfister et al. (1984) at Fort Stanton and Holechek et al. (1982) in the Blue Mountains of Oregon reported green forbs are preferred over dormant grasses. Total forb content increased $(P<.05)$ between February and late
March. Increased diversity of forbs available because of favorable spring precipitation might have been responsible for increased dietary levels consumed.

Carruth sagewort was the major species consumed in both February $(56.6 \%)$ and March (53.0\%). High dietary content of total forbs, in particular sagewort, is in sharp contrast with results obtained by earlier researchers in this study area. Allison et al. (1977) and Havstad et al. (1979) indicated sagewort made up only 15 to $16 \%$ of the diet during January and March, respectively. However, both indicated abundance of sagewort in the diet was a function of the availability of sagewort and other palatable forage. Pfister et al. (1984) found cattle grazing on a similar vegetative type in a rest-rotation system consumed $25-39 \%$ carruth sagewort.

Total forb content of $68.2 \%$ (February) and $78.8 \%$ (March) is in sharp contrast to the $28.7 \%$ (January) and $23.4 \%$ (March) level reported by Havstad et al. (1979). These discrepancies can be accounted for, in part, by 2 confounding factors. First, below average winter precipitation during previous studies, compared with above average precipitation in the current study, may account for dietary composition differences. Although forage production data are not available to make comparisons, precipitation data indicates potential for forb growth. Increased diversity of diets from February to late March support this hypothesis. Second, Havstad et al. (1979) stocked the pasture for only 2 weeks at each sampling, while in the current study, grazing occurred for 6 weeks before each sampling. Thus, discrepancies in forb and grass content of our diets compared with other results, as well as the decline of grass (increase in forbs) with time in this study, is indicative of seasonal climatic differences and a decreasing forage base.

Dietary similarities between the 3 groups of animals was high during both February (91.5\%) and March (88.0\%) sampling periods. Control vs ALF had the highest similarities (91.6\%) across sampling periods followed by CON vs CSC $(89.3 \%)$ and CSC vs ALF (88.3\%).

Organic matter content of diets did not differ $(P>.10)$ between treatments but decreased $(P<.05)$ between February and March

Table 4. Nitrogen fractions ${ }^{1}$ of steer diets supplemented with ground pelleted alfalfa (ALF), cottonseed cake (CSC) or no supplement (CON) on blue grama rangeland in south-central New Mexico.

\begin{tabular}{|c|c|c|c|c|c|c|c|}
\hline \multirow[b]{2}{*}{ Component $\%$} & \multicolumn{2}{|c|}{ Sampling Date } & \multirow[b]{2}{*}{$\mathrm{SE}^{2}$} & \multicolumn{3}{|c|}{ Treatment } & \multirow[b]{2}{*}{$\mathrm{SE}^{2}$} \\
\hline & February & March & & $\mathrm{CON}$ & ALF & $\mathrm{CSC}$ & \\
\hline Crude protein & $10.43^{\mathrm{a}}$ & $12.63^{\mathrm{b}}$ & .54 & 11.06 & 11.06 & 12.50 & .82 \\
\hline Total nitrogen & $1.67^{\mathrm{a}}$ & $2.02^{b}$ & .09 & 1.77 & 1.77 & 2.00 & .13 \\
\hline Soluble nitrogen & $.42^{\mathrm{a}}$ & $.50^{\mathrm{b}}$ & .04 & .47 & .38 & .54 & .04 \\
\hline Insoluble available nitrogen & .86 & .79 & .08 & .83 & .82 & .83 & .11 \\
\hline Insoluble unavailable nitrogen & $.40^{\mathrm{n}}$ & $.73^{\mathrm{b}}$ & .05 & .48 & .58 & .64 & .09 \\
\hline
\end{tabular}

'Nitrogen fractions expressed as a percent of organic matter.

${ }_{2} \mathrm{SE}=$ Standard error of the mean.

${ }^{a-b}$ Period means followed by different letters differ $(P<.05)$. 
Table 5. Total and forage organic matter intakel of steers supplemented with ground pelleted alfalia (ALF), cottonseed cake or no supplements (CON) while grazing blue grama rangeland in south-central New Mexico.

\begin{tabular}{|c|c|c|c|c|c|c|c|}
\hline \multirow[b]{2}{*}{ Intake level } & \multicolumn{2}{|c|}{ Sample Date } & \multirow[b]{2}{*}{$\mathrm{SE}^{2}$} & \multicolumn{3}{|c|}{ Treatment } & \multirow[b]{2}{*}{$\mathrm{SE}^{2}$} \\
\hline & February & March & & CON & ALF & $\mathrm{CSC}$ & \\
\hline $\begin{array}{l}\text { Forage } \\
\text { Total }\end{array}$ & $\begin{array}{r}9.8 \\
13.1\end{array}$ & $\begin{array}{r}8.9 \\
12.1\end{array}$ & $\begin{array}{l}.44 \\
.46\end{array}$ & $\begin{array}{l}10.8 \\
10.8^{\mathrm{a}}\end{array}$ & $\begin{array}{c}7.7 \\
14.1^{\circ}\end{array}$ & $\begin{array}{c}9.6 \\
12.9^{b}\end{array}$ & $\begin{array}{r}1.07 \\
.59\end{array}$ \\
\hline
\end{tabular}

IIntake expressed in grams of intake per $\mathrm{kg}$ of liveweight.

${ }^{2} \mathrm{SE}=$ Standard error of the mean.

${ }^{i b}$ Treatment means followed by a different letter differ significantly $(P<.05)$.

(Table 3). These values are consistent with previous studies at Fort Stanton (Wallace et al. 1983, McCollum 1983). Neutral detergent fiber, ADF, ADL, and OMD, likewise were not affected $(P>10)$ by supplementation. Although ADF and ADL increased slightly $(P>.10)$ and $O M D$ increased $(P<.05)$ between February and March, NDF (February $=80.7 \%$, March $=78.0 \%$ ) showed a general decline $(P>10)$. The slight increase in ADF (February $=62.3 \%$, March $=65.4 \%$ ) and $\mathrm{OMD}$ (February $=42 \%$, March $=48 \%$ ) with a concurrent decline in NDF is indicative of a higher forb content and increasing maturity of the grass component in March. Similar values were reported by McCollum (1983) and Havstad et al. (1979) from these same pastures.

Calcium and $P$ contents of esophageal samples may not be representative of actual consumption because of salivary contamination (Van Dyne and Torell 1964). Calcium levels increased slightly $(P>.10)$ from February $(0.70 \%)$ to March $(0.84 \%)$ and $P$ levels remained constant (February $=0.22 \%$, March $=0.23 \%$ ) while forbs increased in the diet. Carruth sagewort, the major forb, contains fairly high levels of $\mathbf{P}(0.27 \%)$ based on clipped samples (Cordova and Wallace 1975). Major grasses at Fort Stanton (wolftail, blue grama, and sand dropseed) were reported by Pieper et al. (1978) to contain $0.094 \% \mathrm{P}$ in March and $0.102 \% \mathrm{P}$ in February. Calculation of dietary percentage $P$, based on $88.4 \%$ of the diet as wolftail, blue grama, sand dropseed, and carruth sagewort in February and $74.2 \%$ in March, indicates at least $0.18 \% \mathrm{P}$ in February and $0.16 \% \mathrm{P}$ in March. Because the remainder of the diet was forbs, these values can be expected to rise slightly or stay static since forbs are typically high in P (Cordova and Wallace 1975). Phosphorus contamination from saliva makes up about one-half of total bolus $P$ (Little 1972). Results from this study, based on $P$ levels extrapolated from clipped forage and from total bolus $P$ (February $=$ $0.22 \%$ and $0.18 \%$, March $=0.23 \%$ and $0.16 \% \mathrm{P}$ for bolus and clipped results, respectively) indicate the possibility of less than half the bolus $P$ arising from saliva.

Total $\mathbf{N}$ and $\mathbf{N}$ fractions were not affected by treatment (Table 4; $P>.10$ ). However, total N (February $=1.67 \%$, March $=2.02 \%$ ), ADIN (February $=.40 \%$, March $=.73 \%)$ and soluble $\mathrm{N}($ February $=$ $.42 \%$, March $=.50 \%)$ increased $(P<.05)$ between February and late March. Crude protein levels observed in this study are higher than those observed by other researchers at Fort Stanton in January or March. Havstad et al. (1979), Wallace et al. (1983) and Thetford et al. (1971) in January noted $6.4 \%, 8.4 \%$ and $10 \%$ crude protein and in March $6.0 \%, 10.4 \%$ and $7 \%$ crude protein, respectively in fistula samples.

McCollum (1983) stated SN and IAN fractions are of greatest importance to the grazing ruminant because $\mathrm{SN}$ is the primary $\mathrm{N}$ source for rumen microbes and tends to decline with forage maturity. Protein supplements will reverse a decline in total $\mathrm{N}$ intake. However, insoluble $\mathrm{N}$ supplements may not appreciably increase the $\mathrm{SN}$ consumption. In this study, level of supplemental soluble $\mathbf{N}$ $(\mathrm{CSC}=.78 \% \mathrm{SN} ; \mathrm{ALF}=1.21 \% \mathrm{SN})$ did not have an effect on chemical content of the diet selected.

Forage intake did not differ $(P>.49)$ between treatment groups (Table 5) or sampling periods $(P>.90)$. However, there appeared to be a slight reverse relationship between quantity of supplement consumed and forage intake. Increased intake, as a result of pro- tein supplementation has been reported by several researchers (Cook and Harris 1968, Campling 1970, Lusby et al. 1976); however, Rittenhouse et al. (1970) indicated associative effects from protein supplementation are negligible when dietary crude protein is above 6-8\%. Dietary crude protein levels in this study (February $=10.43 \%$; March $=12.63 \%$ ) were greatly above this level, supporting the findings of Rittenhouse et al. (1970).

Total intake (forage + supplement) did not differ between sampling periods $(P>.90)$, but was lower $(P<.05)$ for CON steers $(10.8$ $\mathrm{g} / \mathrm{kg}$ of body weight) than for ALF $(14.1 \mathrm{~g} / \mathrm{kg}$ of body weight) and CSC steers $(12.9 \mathrm{~g} / \mathrm{kg}$ of body weight). Treatment differences reflect additional amounts consumed as supplements, and do not represent an associative effect of supplement on forage intake.

Esophageal masticate crude protein levels reflect adequate crude protein for moderate rates of gain for growing steers (10\% crude protein for $250 \mathrm{~kg}$ steers or heifers gaining $0.7 \mathrm{~kg} /$ day; National Research Council 1976) and heifers or for lactating cows. However, due to low forage intake levels (approximately $275 \mathrm{~g}$ crude protein/day supplied by forage diet), quantities of protein consumed were insufficient for gain $(620 \mathrm{~g}$ crude protein/day for 250 kg steers or heifers gaining $0.7 \mathrm{~kg} /$ day; National Research Council 1976). Cordova et al. (1978) showed intake estimates in grazing cattle vary from 10 to $28 \mathrm{~g}$ of organic matter per kilogram of body weight. Intake levels in this study would fall at the lower end of these estimates. Supplementation with either cottonseed cake or ground, pelleted alfalfa hay would, therefore, appear to be an effective means of providing additional dietary protein.

Overall, protein supplementation in this study did not alter animal plant selectivity based on chemical and botanical composition. Increased intakes with supplementation reported in the literature did not occur in this study. Management of cattle grazing dormant rangeland from a forage habit and consumption basis, may not differ with protein supplementation or type of supplement with dietary crude protein levels observed in this study.

\section{Literature Cited}

Adams, D.C., and R.J. Kartchner. 1983. Effects of time of supplementation on daily gain, forage intake and behavior of yearling steers grazing fall range. Proc. West. Sect. Anim. Sci. 34:158-160.

Allison, C.D., R.D. Pieper, G.B. Donart, and J.D. Wallace. 1977. Fertilization influences cattle diets on blue grama range during drought. $J$. Range Manage. 30:177-180.

AOAC. 1980. Official Methods of Analysis (13th Ed.). Association of Official Analytical Chemists. Washington, D.C.

Campling, R.C. 1970. Physical regulation of voluntary intake. In: A.T. Phillipson (Ed.) Physiology of Digestion and Metabolism in the Ruminant. Oriel Press, New Castle, England.

Conrad, H.R. 1966. Symposium on factors influencing the voluntary intake of herbage by ruminants: Physiological and physical factors limiting feed intake. J. Anim. Sci. 25:227-235.

Cook, C.W., J.T. Blake, and J.W. Call. 1963. Use of esophageal fistula cannulae for collecting forage samples from both sheep and cattle grazing in common. J. Anim. Sci. 22:579-581.

Cook, C.W., and L.E. Harris. 1968. Effect of supplementation on intake and digestibility of range forage. Utah Agr. Exp. Sta. Bull. 475.

Cordova, F.J., and J.D. Wallace. 1975. Nutritive value of some browse and forb species. Proc. West. Sec. ASAS. 26:160-162. 
Cordova, F.J., J.D. Wallace, and R.D. Pieper. 1978. Forage intake by grazing livestock: A review. J. Range Manage. 31:430-438.

Falvey, L. 1977. Response of steers to dry season protein supplementation on improved pastures. Australian J. Exp. Agr. Anim. Husb. 17:724-727.

Goering, H.D., and P.J. Van Soest. 1970. Forage fiber analysis (apparatus, reagents, procedures and some applications). USDA-ARS Handbook No. 379 .

Havstad, K.M., R.D. Pieper, G.B. Donart, J.D. Wallace, F.J. Cordova, and E.E. Parker. 1979. Cattle diets on a fertilized blue grama upland range site. J. Range Manage. 32:398-401.

Heady, H.F. 1964. Palatability of herbage and animal preference. J. Range Manage. 17:76-82.

Holechek, J.L., M. Vavra, J. Skovlin, and W.C. Krueger. 1982. Cattle diets in the blue mountains of Oregon, I. Grasslands. J. Range Manage. 35:109-112.

Langlands, J.P., and J.E. Bowles. 1974. Herbage intake and production of Merino sheep grazing native and improved pastures at different stocking rates. Australian J. Exp. Agr. Anim. Husb. 14:307-315.

Little, D.A. 1972. Studies on cattle with oesophageal fistulae: The relation of the chemical composition of feed to that of the extruded bolus. Australian J. Exp. Agr. Anim. Husb. 12:126-129.

Lusby, K.S., D.F. Stephens, and R. Totusek. 1976. Influence of breed and level of winter supplement on forage intake of range cows. J. Anim. Sci. 43:543-548.

McCollum, F.T. 1983. The influence of advancing season on nutritive quality, intake and rumen fermentation of cattle diets on blue grama rangeland. Ph.D. Diss. New Mexico State Univ., Las Cruces.

National Research Council. 1976. Nutrient Requirements of Domestic Animals, No. 4. Nutrient Requirements of Beef Cattle. Fifth Revised Ed. National Academy of Sciences - National Research Council, Washington, DC.

Oosting, H.J. 1956. The study of plant communities. W.H. Freeman and Company, San Francisco.

Parker, E.E., J.D. Wallace, A.B. Nelson, and R.D. Pieper. 1974. Effects of cottonseed meal supplement and age at first calving on performance of range cattle. New Mexico State University Agr. Exp. Sta. Bull. 627.
Pfister, J.A., G.B. Donart, R.D. Pieper, J.D. Wallace, and E.E. Parker. 1984. Cattle diets under continuous and four-pasture, one-herd grazing systems in southcentral New Mexico. J. Range Manage. 37:50-54.

Pieper, R.D., A.B. Nelson, G.S. Smith, E.E. Parker, E.J.A. Boggino, and C.F. Hatch. 1978. Chemical composition and digestibility of important range grass species in south-central New Mexico. New Mexico State Univ. Agr. Exp. Sta. Bull. 662.

Rittenhouse, L.R., D.C. Clanton, and C.L. Streeter. 1970. Intake and digestibility of winter range forage by cattle with and without supplements. J. Anim. Sci. 31:1215-1221.

Sparks, D.R., and J.C. Malechek. 1968. Estimating percentage dry weight in diets using microscopic technique. J. Range Manage. 21:264-265.

Steele, R.G., and J.H. Torrie. 1980. Principles and Procedures of Statistics (2nd Ed.). McGraw-Hill Book Co., Inc. New York.

Thetford, F.O., R.D. Pieper, and A.B. Nelson. 1971. Botanical and chemical composition of cattle and sheep diets on pinyon-juniper grassland range. J. Range Manage. 24:425-431.

Tilley, J.M.A., and R.A. Terry.1963. A two-stage technique for the in vitro digestion of forage crops. J. Brit. Grassl. Soc. 18:104-111.

U.S. Department of Commerce. 1973. National Oceanic and Atmospheric Administration, Environmental Data Service. Climatology of the U.S. No. 81, Asheville.

Van Dyne, G.M., and H.F. Heady. 1965. Botanical composition of sheep and cattle diets on a mature annual range. Hilgardia. 36:465-470.

Van Dyne, G.M., and D.T. Torell. 1964. Development and use of the esophageal fistula: A Review. J. Range Manage. 17:7-19.

Waldo, D.R., and H.K. Goering. 1979. Insolubility of protein by four methods. J. Anim. Sci. 49:1560-1568.

Wallace, J.D., F.J. Cordova, G.B. Donart, and R.D. Pieper. 1983. Nutritive value of cattle diets on fertilized and unfertilized blue grama rangeland. Proc. Int. Grassld. Cong. 14:688-690.

Weston, R.H., and J.P. Hogan. 1968. Factors limiting the intake of feed by sheep. IV. The intake and digestion of mature ryegrass. Australian $\mathbf{J}$. Agr. Res. 19:567-570. 